\title{
Assessment of Accumulation of Heavy Metals and Lipid Peroxidation in Common reed (Phragmites australis) in the Albanian Part of Lake Ohrid
}

\author{
Enis Dalo', Rigerta Sadikaj², Hazbije Sahiti ${ }^{*}$ \\ 1 Department of Biology, Faculty of Mathematics and Natural Sciences, University of Prishtina, Prishtina, \\ Kosovo \\ 2 Department of Biotechnology, Faculty of Natural Sciences, University of Tirana, Tirana, Albania \\ *Corresponding author's e-mail: hazbije.sahiti@uni-pr.edu
}

\begin{abstract}
The Albanian part of Lake Ohrid is endangered by heavy metals, the source of which is mainly the old mining waste around the lake shore, but also agricultural pollution. The chromium and nickel concentrations were investigated in the fall season in the sediment and common reed (Phragmites australis). The peroxidation of lipids in stalks was also investigated. The study was conducted on three points of the lake: at the entrance to the city of Pogradec, the former Fe-Ni mine and the village of Lin (control point). Heavy metals were determined with the method of atomic absorption spectrometry and malondialdehyde, using the spectrophotometric method. The results showed that there was greater accumulation of nickel than chromium in both sediments and stalks in the three explored points. The sediment and plant samples taken in the part of the former Fe-Ni mines showed a higher level of investigated metals, compared to the other two research points. At this point, the difference was significant for chromium $(p<0.01)$ compared to the village of Lin, whereas for nickel there was a significant difference $(p<0.01)$ for the two research points compared to the reference point (Lin). Concerning the $\mathrm{Cr}$ and $\mathrm{Ni}$ levels in stalk, a significant difference $(\mathrm{p}<0.01)$ was observed for both metals only in the samples taken from the former Fe-Ni mines, compared to the village of Lin. Meanwhile, the increased MDA level caused by oxidative stress was higher in the plants collected at the entrance of Pogradec, not only with the checkpoint $(\mathrm{p}<0.01)$ but also with the plants collected in the former Ni-Fe mine.
\end{abstract}

Keywords: heavy metals; Ohrid Lake; Common reed; MDA; pollution

\section{INTRODUCTION}

It is well known that heavy metals, without exception, cause health problems in all living beings, including aquatic organisms. In addition to health problems, heavy metals affect the aquatic biota through their toxicity and non-biodegradable nature, when they accumulate in sediment (Bonanno et al., 2017). The contamination of soil or water with heavy metals is a serious problem that causes crop decline worldwide (Mohammed, Kapri and Goeland, 2011; Jiang et al., 2014). The current research was conducted in Lake Ohrid, which is one of the deepest and oldest lakes in Europe. The hills and mountains surrounding Lake Ohrid make this lake stand insulated; therefore, it is considered to have a unique water ecosystem of world importance with more than 200 endemic species (Avramovski et al., 2003). Although of great importance, this lake is contaminated. The pollution sources include fertilizers, pesticides, sewage and heavy metals. The source of heavy metal contamination are the old chromium, nickel and iron mines near Lake Ohrid in the part of Albania, which contributed to the high concentrations of chromium, nickel, cobalt and iron in sediment (Malaj et al., 2012). All these pollutants obviously have a negative impact on the animals and plants that live in this lake. Aquatic plants, as the first trophic level of the food chain, take up the heavy metals, and can thus be used as the bioindicators of water contamination with heavy metals (Ganjali et al., 2014). One of the plant species living in Lake Ohrid is Phragmites australis, 
which is a common annual freshwater marsh plant that has importance for environmental pollution because of its ability to absorb the chemical contaminants like heavy metals, in soil or water. (Albrecht and Wilke, 2008; Kumar P. et al., 1995; Hunt AJ. et al., 2014). Due to this ability, Phragmites australis has a potential to be used in artificial floating wetlands for the removal of heavy metals (Huang X. et al., 2017). Chromium, especially the hexavalent chromium may have toxic effects on plant, because of its mobility. In addition to its adverse effects on the growth of roots, stalk and leaves, it has harmful effects on some physiological processes such as photosynthesis, water relations, and mineral nutrition of plants. (Shanker et al., 2005). Nickel, which in nature is mainly found in the form of bivalent ions, is obtained from plant roots with passive diffusion and active transport. Although Ni represents an essential micronutrient for normal plant growth and development, high levels above the allowed limit may adversely affect the functioning of some cell components (Yusuf et al., 2011). Nickel is a component of urease that is essential for the metabolism of nitrogen in high plants. The plants that can accumulate nickel in shoots up to $100 \mathrm{mg} \mathrm{kg}^{-1}$ are known as hyperaccumulators (Bhalerao et al., 2015). Some of the nickel effects in plants include inhibition of photosynthesis, necrosis and chlorosis, redness in germination, alteration of enzymatic activities etc. (Sachan and Lal, 2017).

One of the adverse effects of heavy metals in plants is the production of reactive oxygen species (ROS) which is known as oxidative stress process that causes changes in the structure and function of their cells. Oxidative damages caused by oxidative stress on plants can be measured through the molecules that are formed after the ROS reaction with certain cellular structures and one of these reactions is lipid peroxidation. Malondialdehyde (MDA) constitutes a marker for lipid peroxidation, and protein carbonyl content corresponds to the protein oxidation. In addition to the breakdown of the constituent components of the cell structure, they simultaneously act as an important secondary messenger for inducing a plant defense system (Sytar et al., 2013; Fryzova et al., 2018). The purpose of this research was to assess the environmental pollution in the Albanian part of Lake Ohrid through the accumulation of two metals: chromium and nickel in sediments and plants. Moreover, through the determination of malondialdehyde as a bioindicator of lipid peroxidation enabled to evaluate the oxidative stress of the plant and ascertain what concentrations of metals have influence on increasing the oxidative stress.

\section{MATERIAL AND METHODS}

\section{Study area}

The research was conducted in Ohrid Lake, which is one of the oldest lakes in the world, located in Balkan Peninsula (Popovska and Bonacci 2007). Lake Ohrid is a transboundary lake shared between the Former Yugoslav Republic of Macedonia (FYROM) and the Republic of Albania (Fig. 1). The lake is located at $693.5 \mathrm{~m}$ above sea level and has a maximum length of $30.4 \mathrm{~km}$ $(\mathrm{N}-\mathrm{S})$, a maximum width of $14.7 \mathrm{~km}$ (W-E), surface area of $358 \mathrm{~km}^{2}$, and a tub-shaped bathymetry with a maximum water depth of $293 \mathrm{~m}$, a mean water depth of $\sim 151 \mathrm{~m}$, and a total volume of $50.7 \mathrm{~km}^{3}$ (Wagner et al., 2017). Despite the fact that the Lake Ohrid is under the influence of the anthropogenic factor, this lake is still considered as an oligotrophic lake with high amounts of dissolved oxygen in the deep waters (Matzinger et al., 2007). Another special characteristic of this ecosystem is high biodiversity and extremely high endemicity rates, Ohrid Lake hosts various endemic species from the entire food chain (Albrecht and Wilke, 2008; Trajanovska et al., 2014).

\section{Sampling}

The research was conducted in the autumn of 2014. The sampling was done at three points in Lake Ohrid: on the side that belongs to Albania, precisely at the entrance of Pogradec (area occupied by Phragmites australis), near the former $\mathrm{Fe}-\mathrm{Ni}$ mine and in the village of Lin. Lin village has served as a reference point due to its distance from the mine. The samples of macrophytes were collected by hand from the shore of the lake, then the leaves were removed and only the stalks were placed in sterile glasses filled with the water taken from the lake. The prepared samples were brought to the laboratory in ice containers at a temperature of about $5^{\circ} \mathrm{C}$, then part of the stalks and sediments were dried at room temperature while the rest stalk was placed at a temperature of $-20^{\circ} \mathrm{C}$. A total of 18 surface sediment samples (0-5 cm depth) were collected in the three sampling points. Then, the samples were put in sterile plastic glass. 


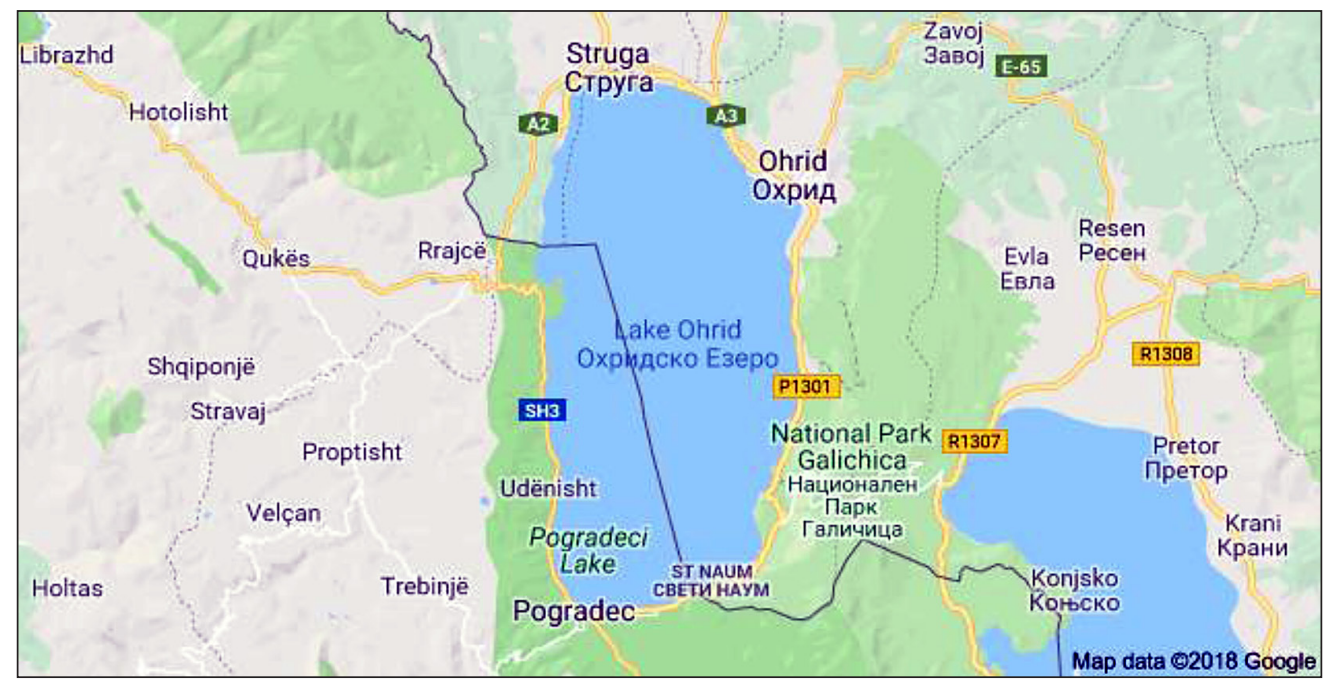

Figure 1. Map of Lake Ohrid (https://www.google.com/maps/place/Lake+Ohrid)

\section{Determination of physicochemical parameters}

The temperature and $\mathrm{pH}$ were measured at the three sampling points. The water temperature was measured with water thermometer and $\mathrm{pH}$ with Inolab WMW Series pH Meter.

\section{Determination of heavy metals}

The heavy metals were determined with the atomic absorption spectrometry (AAS) method by means of the Perkin-Elmer 1200 B model apparatus. The samples of sediment and plant were initially dried at room temperature and then subjected to liquid mineralization. The dry materials (0.5-1 g) were diluted with $10 \mathrm{ml}$ of concentrated nitric acid $\left(\mathrm{HNO}_{3}\right)$ and $10 \mathrm{ml}$ of concentrated hydrochloric acid $(\mathrm{HCl})$ at a temperature of $400^{\circ} \mathrm{C}$ for about 1 hour. Then the mineralized samples were mixed with distilled water and filtered with Whatman $0.45 \mu \mathrm{m}$ filtration paper. The filter was placed in volumetric flask with a volume of 50 $\mathrm{ml}$ and was leveled up to the mark with distilled water. The AAS calibration was done with a standard of 1000 ppm for each element.

\section{Determination of malondialdehyde}

Malondialdehyde (MDA) was determined according to Heath and Packer 1968, with some modifications. The principle of this method is based on the reaction of MDA with thiobarbituric acid, whereby a colored complex is formed. First$1 y$, the frozen samples of plant stems with countermeasure $0.5 \mathrm{~g}$ were homogenized with $10 \%$ tricloracetic acid (TCA). Then the homogenate was centrifuged at $7000 \mathrm{Xg}$ for 10 minutes. One $\mathrm{ml}$ homogenate was mixed with two $\mathrm{ml}$ of $0.5 \%$ thiobarbituric acid dissolved in 10\% TCA. This mixture was placed at $95^{\circ} \mathrm{C}$ for 45 minutes and then cooled to the room temperature. After centrifugation, the formed color was read at $532 \mathrm{~nm}$ in the spectrophotometer. The calculation of the MDA value was done with extinction coefficient $1.56 \times 105 \mathrm{M}^{-1} \mathrm{~cm}^{-1}$ expressed as micromole MDA per gram of wet tissue.

\section{Data analysis}

The bioconcentration factor (BCF), which implies the ability of the plants to absorb metals from the substrate, was calculated as the ratio of metal concentrations in plants and sediments:

$$
B C F=\text { Plant }[\text { Metal }] /[\text { Metal }] \text { sediment }
$$

\section{Statistical analysis}

The differences between the points were expressed using ANOVA and a Post Hoc Tukey test. Data were expressed as means \pm standard error (SE) for each samples $(n=6)$ for heavy metals and $(n=3)$ for MDA. P values of $\mathrm{p} \leq .0 .01$ were considered to be significant.

\section{RESULTS AND DISCUSSION}

\section{Physicochemical parameters}

Table 1 shows the values of physicochemical parameters. The temperature measurements between the three points did not show a major 
change $\left(19-19.5^{\circ} \mathrm{C}\right)$, and the measured values are in accordance with the EU [1989] Directives $\left(25^{\circ} \mathrm{C}\right)$. Similarly, in the case of the $\mathrm{pH}$ values, there is no major difference between the measuring points and they range from 7.93 to 8.54 , which are also in line with the EU Directives [1989] (5.5-8).

Lake Ohrid as one of the oldest lakes in Europe along with the Prespa and Shkodra Lakes are located along the Drini and Buna rivers. This lake, which is characterized by its endemic fauna, is endangered by pollution. The sources of this contamination are agriculture, metallurgical, chemical and mining industries (CSBL Conservation and Sustainable Use of Biodiversity at Lakes Prespa, Ohrid and Shkodra / Skadar). Moreover, the natural serpentine soils of the Pogradec district endanger the quality of water (Bani et al., 2013). Heavy metals are mainly derived from the mines that are present around the lake shore and most of them are now inoperative. These mines produced chromium, nickel, iron and coal in the past. Even today, these mines pose a risk of heavy metal pollution because their remains containing heavy metals are transferred to lakes through erosion (Avramovski et al., 2003). Once these metals enter the lake, they can be accumulated mainly in sediment, but also in water as well as aquatic plants of the lake and aquatic animals that live there. From this point of view, we have investigated the accumulation of two metals that are characteristic of the lake (chromium and nickel) on the stalk of Common reed (P. australis) and in the sediment taken from the three points of lake shore. The results of the current research are presented in Table 2.
Ohrid Lake is characterized by low diversity of aquatic macrophytes. They are located in four areas, i.e. Cladophora zone, Phragmites australis zone, Potamogeton zone and Chara zone (Albrecht et al., 2008). The object of current research is the $P$. australis plant that is very widespread in the shore of the Albanian part of Lake Ohrid. Through the roots, macrophytes have the ability to absorb heavy metals from contaminated sediments more than from water. (Zvolsman et al., 1993; Bonanno et al., 2009).

From the results presented in Table 2 it is seen in general that the $\mathrm{Ni}$ values were higher than those of $\mathrm{Cr}$, both in sediments as well as in the plants of the three sampling points. The highest values of the two investigated metals ( $\mathrm{Ni}$ and $\mathrm{Cr}$ ) were recorded in the sediment and plants collected at the point of iron and nickel mine $\left(\mathrm{Ni}=109.90 \mathrm{mg} \mathrm{kg}^{-1}, \mathrm{Cr}=78.33 \mathrm{mg} \mathrm{kg}^{-1}\right.$, $\mathrm{Ni}=8.71 \mathrm{mg} \mathrm{kg}^{-1}, \mathrm{Cr}=4.35 \mathrm{mg} \mathrm{kg}^{-1}$ ), while the lower ones for both metals were recorded in the sediment and the plants collected at Lin $\left(\mathrm{Ni}=16.96 \mathrm{mg} \mathrm{kg}^{-1}, \mathrm{Cr}=13.88 \mathrm{mg} \mathrm{kg}^{-1}\right.$, $\mathrm{Ni}=3.28 \mathrm{mg} \mathrm{kg}^{-1}, \mathrm{Cr}=1.15 \mathrm{mg} \mathrm{kg}^{-1}$ ), which was taken as the reference point, due to the low level of heavy metals in the sediment and plant samples. In a research conducted by Shehu et al. (2017) in four stations of the Albanian part of Lake Ohrid, which are in line with our three stations and the village of Lin also taken as a reference point due to the low level of heavy metals, the highest chromium values were found in the point N-E Pogradec S1, point S2 of the Tushemisht town and $\mathrm{S} 3$ point of the $\mathrm{Fe}-\mathrm{Ni}$ mine, rather than in the eastern part of the village of Lin, point S4. The chromium values in Ohrid Lake were compared to those of the Albanian part of Prespa

Table 1. Physicochemical parameters of water in three sampling points of Lake Ohrid

\begin{tabular}{|c|c|c|c|}
\hline Parameters & Entry of Pogradec & Former Fe - Ni mine & Lin village \\
\hline Temperature & 19 & 19.5 & 19 \\
\hline $\mathrm{pH}$ & 8.39 & 7.93 & 8.54 \\
\hline
\end{tabular}

Table 2. Chromium and nickel values in sediment and in stalk of Common reed (Phragmites australis) at three sample points on the Albanian side of Lake Ohrid

\begin{tabular}{|c|c|c|c|}
\hline Element & Entry of Pogradec & Former Fe-Ni mine & Lin village \\
\hline \multicolumn{4}{|c|}{ Sediment } \\
\hline $\begin{array}{l}\mathrm{Cr}\left(\mathrm{mg} \mathrm{kg}^{-1}\right) \\
\mathrm{Ni}\left(\mathrm{mg} \mathrm{kg}^{-1}\right)\end{array}$ & $\begin{array}{c}41.10 \pm 19.33 \\
82.78 \pm 17.88^{* *}\end{array}$ & $\begin{array}{c}78.33 \pm 26.73^{* *} \\
109.90 \pm 26.67^{* *}\end{array}$ & $\begin{array}{l}13.88 \pm 5.76 \\
16.96 \pm 7.59\end{array}$ \\
\hline \multicolumn{4}{|c|}{ Stalk } \\
\hline $\begin{array}{l}\mathrm{Cr}\left(\mathrm{mg} \mathrm{kg}^{-1}\right) \\
\mathrm{Ni}\left(\mathrm{mg} \mathrm{kg}^{-1}\right)\end{array}$ & $\begin{array}{l}2.33 \pm 0.54 \\
5.87 \pm 1.76\end{array}$ & $\begin{array}{l}4.35 \pm 1.50 \text { ** } \\
8.71 \pm 2.23^{* *}\end{array}$ & $\begin{array}{l}1.15 \pm 0.41 \\
3.28 \pm 1.04\end{array}$ \\
\hline
\end{tabular}

(The results are presented as Mean $\pm \mathrm{SD}$, significant to the reference point of $\operatorname{Lin} * * \mathrm{p}<0.01$ and $* \mathrm{p}<0.05)(\mathrm{n}=6$ ) 
Lake and were 6 times higher in Lake Ohrid than in Lake Prespa. However, the high chromium values in Lake Ohrid do not threaten the lake because they are lower than the values recommended by the EU Directive [78/659 / EEC]. Similarly, the results with respect to nickel showed that the values were twice as high in Ohrid as compared to Prespa. On the other hand, the lower nickel values were recorded at Lin's station, compared to other stations. These values for nickel in all four stations were lower than the recommended value of the [78/659 / EEC] EU Directive. High amounts of $\mathrm{Cr}$ and $\mathrm{Ni}$ in sediment and plants (P. australis) were also found by Malaj et al. 2012. According to Malaj et al. 2012, Lake Ohrid sediment serves as the major sink for heavy metals, especially in the sites influenced by contaminated sources like waste mineral dumps or discharge points from the tributaries. Similar findings were also found by Vogel et al. (2011) in his research conducted in the southwestern part of Ohrid Lake. According to Vogel et al. (2011), high valuse of chromium, nickel and magnesium in sediment, are distributed from the southwest to the south and then to the east of the lake.

The results of several studies conducted in the Lake Ohrid sediment, showed high values of chromium and nickel. These results indicate that these two metals were accumulated more by the plants. According to Bonanno et al., 2010, the roots show a greater tendency for accumulation compared to the stem. The mentioned authors ascertain lower values of the $\mathrm{Ni}$ and $\mathrm{Cr}$ accumulation on the stem, compared to the accumulation values of these metals in the stem within the current research.

Table 3 shows the bioconcentration factor index. The data presented in this table indicates that the highest BFC value was found in the plant samples taken in Lin village along with the samples taken at two other sampling points, although the amount of heavy metals was the highest in these two points. In this case, BFC for Ni is higher than for Cr. This can be justified by the fact that the nickel is an essential micronutrient and according to Berry and Wallace (1981) the dose-response curves for essential heavy metals show deficiency at suboptimal concentrations, tolerance at optimal concentrations (including the potential of the plants to maintain homeostasis) and toxicity at high concentrations. The heavy metal uptake from plants is affected by several factors such as $\mathrm{pH}$, water content, and organic substances; however, seasonal changes can also have influence on the accumulation of heavy metals. A study conducted in Sapanca Lake in Turkey with two aquatic plants, $P$. australis and $S$. lacturis showed that the chromium and nickel accumulation changed from season to season. Even the different parts of the plant like root, rhizome and shoot exhibited different accumulation. Both plants are called root accumulators due to the large concentration of metals found in the root. During the analysis of the accumulation factor for roots, it was found that it was larger at the $P$. australis plant than at the $P$. lacturis plant and the major changes due to the accumulation factor appeared in autumn and winter. The highest accumulation factor was found in the root for $P$. australis in winter while in shoot for S. lacturis for stem (Duman et al, 2007). According to Duman et al., the values obtained for the shoot in autumn are similar to the current research values, but the value of nickel accumulation is lower than that of chromium. This may be justified by the fact that the serpentine lands contributed to the accumulation of nickel more by the plants in Ohrid than in Sapanca. Heavy metals in general, and in this case chromium and nickel, may have toxic effects on plants. According to Allen et al. (1974), the chromium values of $0.5 \mathrm{mg} \mathrm{kg}^{-1}$ and nickel over the value of $5 \mathrm{mg} \mathrm{kg}^{-1}$ are toxic to plants. In the current research, the toxic values of both metals were ascertained at all points except the point of Lin for nickel.

Excessive intake of heavy metals can interfere with cellular metabolism by increasing the production of ROS through auto-oxidation. Reactive oxygen species (ROS) can then cause cellular damage, as well as oxidation of lipids. One of the molecules that is formed during lipid peroxidation is malondialdehyde (MDA).

Quantitative determination of malondialdehyde provides the knowledge on the rate of lipid peroxidation and by this also the oxidative stress caused by the toxicity of heavy metals (Sytar et al., 2013; Fryzova et al., 2018). In the current research, MDA was determined on the stalk of the

Table 3. Bioconcentration factor of stalks in Common reed (Phragmites australis) at three sample points on the Albanian side of Lake Ohrid

\begin{tabular}{|c|c|c|c|}
\hline Element & Entry of Pogradec & Former Fe-Ni mine & Lin village \\
\hline $\mathrm{Cr}$ & 0.056 & 0.055 & 0.082 \\
$\mathrm{Ni}$ & 0.070 & 0.079 & 0.193 \\
\hline
\end{tabular}


Table 4. MDA values in stalk of Common reed (Phragmites australis) at three sample points on the Albanian part of Lake Ohrid

\begin{tabular}{|c|c|c|c|}
\hline Unit & Entry of Pogradec & Former Fe-Ni mine & Lin village \\
\hline$\mu \mathrm{mol}$ MDA/g wet tissue & $10.11 \pm 0.46^{* *}$ & $8.70 \pm 0.32$ & $7.63 \pm 0.99$ \\
\hline
\end{tabular}

(The results are presented as Mean \pm SD, significant to the reference point of Lin $* * p<0.01$ and $* p<0.05)(n=3)$

plants obtained at the three investigated points. The MDA values are shown in Table 4.

The results from Table 4 show that higher MDA values were recorded on the stalk of the plants collected at the Pogradec entry point, compared to those collected at the former Fe-Ni mine point. The difference in the MDA values on the stalk of the plants of Pogradec entry point compared to those of Lin point is significant $(\mathrm{p}<0.01)$. Alfadul et al., (2013) studied the effect of some heavy metals $(\mathrm{Zn}, \mathrm{Cu}, \mathrm{Cd}, \mathrm{Pb})$ in $P$. australis in the production of free radicals by measuring MDA as the lipid peroxidation parameter. Under the influence of the stress caused by heavy metals, the MDA level in the leaves increased. The increase of the metal concentration also increased the MDA to a certain degree. However, the further increase ended with the MDA decrease. According to the authors, the antioxidant enzymes that fought off the generating of free radicals had impact on high concentrations. Additionally, it was found out that MDA values depend on the metal concentration which increases nickel and may have toxic effects on plants. (Zvolsman et al., 1993). At the same time, this metal can also cause increased lipid peroxidation. Another research done with Lemna gibba which was exposed to nickel with different concentrations $\left(0-20 \mathrm{mg} \mathrm{L}^{-1}\right)$ showed a significant increase in MDA value by increasing the concentration of metal. The largest accumulation of nickel occurred in the dose of $0.5 \mathrm{mg} \mathrm{L}^{-1}$ of $\mathrm{Ni}$ and then there was a decrease in accumulation, while the MDA had a significant increase up to the dose of $20 \mathrm{mg} \mathrm{L}^{-1}$ of Ni (Demirezen Yilmaz et al., 2011). Not only nickel but also the exposure to chromium stimulates lipid peroxidation (Pal Singh et al., 2013). A study of rice seedlings showed MDA increase after 18 hours of chromium hexavalent treatment. MDA increase continued even up to 48 hours of treatment. No MDA increase was observed in the first hours of treatment (2, 6 and 12 hours). (Panda, 2007). In our research, P. australis collected at the point of the former Fe-Ni mines showed greater accumulation of chromium and nickel compared to the plants collected at the other two points. Despite the fact that the amount of heavy metals accumulated in these plants was higher at this point, the MDA level was lower than that of the plants picked at the point of entry of the city. This can be justified by the fact that at the entrance of Pogradec, in addition to heavy metals, agricultural and urban factors may promote the production of free radicals.

\section{REFERENCES}

1. Albrecht C., Wilke T. 2008. Ancient Lake Ohrid: biodiversity and evolution. Hydrobiologia, 615, 103-140.

2. Alfadul SMS., Al-Fredan MAA. 2013. Effects of $\mathrm{Cd}, \mathrm{Cu}, \mathrm{Pb}$, and $\mathrm{Zn}$ combinations on Phragmites australis metabolism, metal accumulation and distribution. Arab. J. Sci. Eng., 38, 11-19.

3. Allen, S.E. 1989. Chemical Analysis of Ecological Material. Blackwell, Oxford.

4. Avramoski O., Kycyku S., Naumoski T., Panovski D., Puka V., Selfo L., Watzin M. 2003. Lake Ohrid: experience and lessons learned brief (Lake Basin Management Initiative). n.d. Web 06 Oct 2012. http://www.ilec.or.jp/eg/lbmi/index.htm

5. Bani A., Imeri A., Echevarria G., Pavlova D., Reeves R.D., Morel J.L., Sulçe S. 2013. Nickel hyperaccumulation in the serpentine flora of Albania. Fresenius Environmental Bulletin, 22, 1792-1801.

6. Berry WL., Wallace A. 1981 Toxicity - the concept and relationship to the dose-response curve. J Plant Nutr, 3, 13-19.

7. Bhalerao SA., Sharma AS., Poojari AC. 2015. Toxicity of nickel in plants. International Journal of Pure and Applied Biosciences, 3, 345-355.

8. Bonanno G., Borg J.A., Di Martino V. 2017. Levels of heavy metals in wetland and marine vascular plants and their biomonitoring potential: a comparative assessment. Sci. Total Environ., 576, 796-806.

9. Bonanno G., Giudice RL. 2010. Heavy metal bioaccumulation by the organs of Phragmites australis (common reed) and their potential use as contamination indicators. Ecol. Indic., 10, 639-645.

10. CSBL Conservation and Sustainable Use of Biodiversity at Lakes Prespa, Ohrid and Shkodra/ Skadar. Initial characterization of Lakes Prespa, Ohrid and Shkodra/Skadar. Published by Deutsche Gesellshaftfuer Internazionale Zusammenarbeit. Tirana, 2015. 
11. Duman F., Cicek M., Sezen G. 2007. Seasonal changes of metal accumulation and distribution in common club rush (Schoenoplectus lacustris) and common reed (Phragmites australis). Ecotoxicology, 16, 457-463.

12. Fryzova R., Pohanka M., Martinkova P., Cihlarova H., Brtnicky M., Hladky J., Kynicky J. 2018. Oxidative Stress and Heavy Metals in Plants. Reviews of environmental contamination and toxicology, 245, 129-156.

13. Gakwavu R.J., Sekomo B.C., Nhapi I. 2012. Zinc and chromium removal mechanisms from Industrial wastewater by water hyacinth, Eichhornia crassipes (mart.) Solms. - Applied ecology and environmental research, 10, 493-502.

14. Ganjali S., Tayebi L., Atabati H., Mortazavi S. 2014. Phragmites australis as a heavy metal bioindicator in the Anzali wetland of Iran. Toxicol. Environ. Chem., 96, 1428-1434.

15. Huang X., Zhao F., Yu G., Song C., Geng Z., Zhuang P. 2017. Removal of $\mathrm{Cu}, \mathrm{Zn}, \mathrm{Pb}$, and $\mathrm{Cr}$ from Yangtze Estuary Using the Phragmites australis Artificial Floating Wetlands. Biomed Res Int., 6201048, 1-10.

16. Hunt A. J., Anderson C. W. N., Bruce N., García A. M., Graedel T. E., Hodson M., Meech J., Nassar N. T., Parker, H. L., Rylott E. L., Sotiriou K., Zhang Q., Clark J. H., 2014. Phytoextraction as a tool for green chemistry. Green Processing and Synthesis, 3, 3-22.

17. Jiang WJ., Cai Q., Xu W., Yang MW., Cai Y., Dionysiou DD., O'Shea KE. 2014. Cr(VI) adsorption and reduction by humic acid coated on magnetite. Environmental Science and Technology, 48, 8078-8085.

18. Kumar P.B.A.N., Dushenkov V., Motto H., Raskin I. 1995. Phytoextraction: the use of plants to remove heavy metals from soils. Environmental Science \& Technology, 29, 1232-1238.

19. Malaj E., Rousseau P.L. D., Laing D. G., Lens N.L. P. 2012. Near-shore distribution of heavy metals in the Albanian part of Lake Ohrid. Environ Monit Assess, 184, 1823-1839

20. Matzinger A., Schmid M., Veljanoska-Sarafiloska E., Patceva S., Guseska D., Wagner B., Müller B., Sturm M., Wüest A. 2007. Eutrophication of ancient Lake Ohrid: Global warming amplifies detrimental effects of increased nutrient inputs. Limnol. Oceangr., 52, 338-353.

21. Mohammed A.S., Kapri A., Goeland R. 2011. Heavy metal pollution: source, impact, and remedies. Environmental Pollution, 20, 1-28.

22. Popovska C., Bonacci O. 2007. Basic data on the hydrology of Lakes Ohrid and Prespa. Hydrological Processes, 21, 658-664.

23. Sachan P., Lal N. 2017. An overview of nickel $(\mathrm{Ni} 2+)$ essentiality, toxicity and tolerance Strategies in plants. Asian Journal of Biology, 2, 1-15.
24. Seregin IV., Kozhevnikova AD. 2006. Physiological role of nickel and its toxic effects on higher plants. Russian Journal of Plant Physiology, 53, 257-277.

25. Shanker AK., Cervantes C., Loza-Tavera H., Avudainayagam S. 2005. Chromium toxicity in plants. Environment international, 31, 739-75.

26. Shehu A., Vasjari M., Duka S., Vallja L., Broli N., Comparative study of the environmental state of Ohrid and Prespa Lakes, Albania. European Water, 58, 237-244.

27. Singh H., Mahajan P., Batish D, Kohli R. 2013. Chromium toxicity and tolerance in plants. Environmental Chemistry Letter, 11, 229-254.

28. Sytar O., Kumar A., Latowski D., Kuczynska P., Strzałka K., Prasad M. N. V. 2013 Heavy metalinduced oxidative damage, defense reactions, and detoxification mechanisms in plants. Acta Physiologiae Plantarum, 35, 985-999.

29. Trajanovska S., Talevska M., Imeri A., Schneider S. 2014. Assessment of littoral eutrophication in Lake Ohrid by submerged macrophytes. Biologia, 69, 756-764.

30. Vogel H., Wessels M., Albrecht C., Stich H.-B., Wagner B. 2010. Spatial variability of recent sedimentation in Lake Ohrid (Albania/Macedonia). Biogeosciences, 7, 3333-3342.

31. Wagner B., Wilke T., Francke A., Albrecht C., Baumgarten H., Bertini A., Combourieu-Nebout N., Cvetkoska A., D’Addabbo M., Donders T. H., Föller K., Giaccio B., Grazhdani A., Hauffe T., Holtvoeth J., Joannin S., Jovanovska E., Just J., Kouli K., Koutsodendris A., Krastel S., Lacey J.H., Leicher N., Leng M.J., Levkov Z., Lindhorst K., Masi A., Mercuri A. M., Nomade, S., Nowaczyk N., Panagiotopoulos K., Peyron O., Reed J.M., Regattieri E., Sadori L., Sagnotti L., Stelbrink B., Sulpizio R., Tofilovska S., Torri P., Vogel H., Wagner T., Wagner-Cremer F., Wolff G.A., Wonik T., Zanchetta G., Zhang X.S. 2017. The environmental and evolutionary history of Lake Ohrid (FYROM/Albania): interim results from the SCOPSCO deep drilling project, Biogeosciences, 14, 2033-2054.

32. Yilmaz DD, Parlak KU. 2011. Nickel-induced changes in lipid peroxidation, antioxidative enzymes, and metal accumulation in Lemna gibba. Int J Phytoremediation, 13, 805-817.

33. Yusuf M., Fariduddin Q., Hayat S., Ahmed A. 2011. Nickel: An Overview of its uptake, Essentiality and toxicity in plants. Bulletin of Environmental Contamination and Toxicology, 86, 1-17.

34. Zwolsman J.J.G., Berger G.W., Van Eck G.T.M. 1993. Sediment accumulation rates, historical input, postdepositional mobility and retention of major elements and trace metals in salt marsh sediments of the Scheldt estuary, SW Netherlands. Mar. Chem., 44, 73-94. 